\title{
Political Wrestle Was Behind the Appearance of the Syekh Nuruddin Arraniri's Literature Work (Controversial Case of Wahdah Al Wujud in the Classical Malay Literature)
}

\author{
Muhammad Abdullah \\ \{abdullahabah47@gmail.com\} \\ Universitas Diponegoro, Indonesia
}

\begin{abstract}
By translating many books of jurisprudence and Sufism in Javanese, KH Sholeh Darat delivered a message of da'wah at the house of the Regent of Demak which was the uncle of R.A. Kartini. KH Sholeh Darat translates the Quran in Javanese using Arabic Pegon. The book was recorded as the first translation book in the world in Javanese. The first book of interpretation in Arabic Javanese Pegon was given the name Faidhur Rohman. In his missionary ethos, KH Soleh Darat was very concerned about how Javanese culture and character education of Javanese people lack understanding in Arabic. Therefore, the effort to translate various books into banhasa Jawa is nothing more than the process of Javanese Islamization which is very accommodating to Javanese culture. One of the books that reveals the Javanese ethic of Sufism is the Syarah Al Hikam Book. This research is based on the consideration that the manuscript includes some of the cultural riches of the archipelago of the past century which until now can still be saved. Therefore, this manuscript needs to be studied philologically and thematically, especially the values of the propaganda of KH Sholeh Darat which provide a wind of harmony in religion. Through intertextual studies this study intends to find the character relationship of Syarah Al Hikam KH Soleh Darat. Through the learning of the Al Hikam book, traces of Islamic thought and the method of da'wah that combines Islamic culture and Javanese culture, accommodating, moderate, between the Shari'a and the tarekat is the harmonization of Islam can be accepted in the multicultural society in Semarang and Java in the 19th century.
\end{abstract}

Keywords: Islamization, Al-Hikam, Character Education, Multicultural.

\section{Introduction}

In the Malay Sufisme tradition, as thought by Muhyiddin Ibn 'Arabi, Hamzah Fansuri and Syamsudin Sumantri in Malay region, their poems many use broad metaphors to illustrate relation between the last "The Existence" and the world of phenomena. The two most influential metaphors of Javanese thought (in this case Kejawen) are waves in the sea and grow up from one origin. Or in the sufi term of Jalaludin Rumi between mirror and shadow. Relationship "The Existence" and the world of existence, in the Javanese and Malay texts appear in theories of the Sufism of Wahdah Al-Wifat (Wujudiyah) and the "Martabat Tujuh" (Seven Levels of Existence) [1][2].

The sufistic conception of Wahdah al-Wujud and Martabat Tujuh also appears in doctrine of the Javanese Islamic mysticism as explained in the Rambang manuscript. The summary of this manuscript describes doctrine of Javanese Islamic mysticism, either from theological 
aspects, sufistic, or ubudiyah that tend to syar'iyyah. To find out how the efect form of doctrine of Javanese islamic mysticism, in the below will desclosed and analyzed the essence of Rambang.

The relevance of religious literature and state power, or the tension between the literary and ruling politics always occurred throughout history. The relation can have many meanings and dimensions. Sometimes literary works can be commander, ruling politics as commander, but the tendency, the religious literary works just an instrument of power. Poets or authors must be out of action and unproductive under the order of authorities. This last one is what often happens. Political stage that resist of freedom and independence to authors can be seen in the literary map of classical Nusantara, as in the works of Classical Malay.

There are several cases as empirical evidence of tension between religious literature and political power in the manuscript Classical Malay.

First, can be seen in the publication of Nurrudin Ar-Raniri's works. Among others are the manuscript of Asrar Al-Insan fi Ma'rifati Ar-Ruh wa Rahman (The Secret of Human in Identify of Soul and God) published order by Sultan Iskandar Tsani. The background of the work was published to counter the idea of Wahdat Al-Wujud by Hamzah Fansuri, which was considered deviant, who politically threatened the ethos of power because it was considered to threaten the status quo. Therefore, this ideology must be banned from the Malay land. Wahdat Al-Wujud is a philosophical Sufism by Ibn 'Arabi. As Sheikh al-Akbar, or 'great mufti' was born in Murcia 1165, Spain. Ibn 'Arabi wrote a number of great works, among others are Al-Futuhat alMakkiyyah, ' The Revelations of Mecca' consisting of 560 volumes and Fusus al-Hikam, 'The Phase of Knowledge' which are both as encyclopedia of Sufism (Thohari, 1991). Futuhat alMakkiyyah, as the author explains, is dictated by God through the angels (the giver of revelation), while the Fusus al-Hikam is written by the inspiration of the Prophet Muhammad. Most notable the entire system of Ibn 'Arabi was generally characterized by the term wahdat alwujud, "unity of existence" [3]. In the world of Malay literature, the thought of Ibn Arabi, developed by Hamzah Fansuri and Syamsudin, also raised political issues and disunity to the Muslims.

Second, other books of Nurudin that similar with the book of Asrar al-Insan is Tibyan fi Ma'rifatil Adyan (The Explanation in Understanding the Religions). In the beginning of this book, stated during the time of Sultan Iskandar Tsani, Nuruddin Ar-Raniri had a fierce opposition with the doctrine of Wujudiyah of what he assumes as infidel and mulhid. Even Nurudin says that Wujudiyah adherent have to killed. After the death of Sultan Iskandar Tsani. Nuruddin received orders from Queen Syafiyatuddin Syah to write his book. The strong motivation behind the birth of this book was stopped the thought of Wujudiyah from Hamzah Fansuri. The second motive was to doctrine the right religion, about the importance of Islamic law to Muslims at that time.

Third, the other manuscript is Durrat Al-Fara'id an Assyrian theological thought that one sect with the ruler of Sutan Iskandar Tsani in the Sultanate of Aceh Darussalam. This book was written to counter the doctrine of mu'tazilah, as rationalist theology that began to grow up among the Muslims of the Malay at that time. In principle the Asy'ariyah theology dissmilar ways to the mu'tazilah theology, especially conceive to the primary texts of religion. Indeed, figure out the primary texts of the Quran and Al-Sunnah, the Asy'ariyah to take the middle ways or synthesis between the literal method of the Hambali and the Mu'azilah. That is why Asy'ariyah method was satisfactory way out for many people. And it was the main reason why the Asy'ariyah as universally accepted in the Islamic world. And that was why the Asy'ariyah still strong enough in Islamic society to this day. 
Fourth, another manuscript that have political theme, is Sirat al-Mustaqim by Sheikh Nuruddin Ar-Raniri. There were two reasons the birth of Sirāt al-Mustaqīm, (1) the political motive, which is based on fact that time the Muslims in Aceh were following the sect of Hamzah Fansuri and Syamsudin As-Sumatrani who have thought of Wujüdiyah. A pattern of the Sufism philosophy by Ibn 'Arabi's, which says that God has a similar to beings (tasybīh). Because of Nuruddin's view assum this doctrine was heresy, he should write a book of jurisprudence to suggest on Aceh Muslims return to the right ways, the way of truth (sira $\bar{a}^{-}$al-mustaqim), as explain in the book. Reason (2), the book was born request by Nuruddin's best friend, for he wrote the book of jurisprudence based on the Imam Syafi'i sect (Tjokrowinoto, 1964).

\section{Concept of Wahdah al Wujud: The Political Trigger of the Ruler}

As alluded to in chapter one, many Malay texts were born and written due to certain political situations. The prominent political factors were greatly influenced by the interests of the sultan and the people around him, such as the great mufti, especially during the reign of Aceh Darussalam under Sultan Iskandar Tsani and Sultanah Safiyatuddin Syah.

An early factor as master of conflict or the trigger for political texts emersion were the religious idea in Aceh society, which were the spread of Wahdat al-Wifat (Wujudiyah), concept by Hamzah Fansuri and Syamsudi As-Sumatrani. Some Acehnese scholars were declared that Wahdat Al-Wujud could mislead Muslims.

After the reading of Malay manuscripts, such as Asrar Al-Insan, Durrat Al-Fara'id, Sirat Al-Mustraqim, and Tibyan Fi Ma'rifati Adyan by Nuruddin Ar-Raniri, can be explained that the phenomena and constelation of Islamic ideology in the form dichotomous idea in the world of literature, especially in the sense of wahdat al-wujud, are not explicitly mention by all the texts. It is only in the Tibyan fi Ma'rifatil Adyan offended by Nurudin in the beginning. Therefore, to trace the hegemonic traces of Aceh sultanate's power in the realm of religion, in particular intervention in the understanding of wahdat al-wujud, it can be studied from the historical aspect the origin of this manuscripts.

\section{Research Methods}

In order to support the input of data information, this study will be conducted using the method; (1) the method of philology as the textual method of producing text edits, (2) the literature review method, which is for the analysis of the textual content that reveals the political meaning of the Malay texts. The text content analysis method will use thematic and hermeneutic methods. Method of text analysis with a thematic approach is an approach to theological text by finding and reviewing the central themes of the text. The first step is by reading in-depth, studying, understanding the themes of a text, and looking for meanings that appear in the text (Sumaryono, 1999; Bleicher, 2003; Ricoeur, 2002). In other words, this thematic approach is used to understand the text and interpret the text so that the remaining meanings can be explained and understood correctly.

\section{Result and Discussion}




\subsection{The Sultan Aceh's Political Controversy over the Birth of Malay Literature}

Power is often exercised by a ruler who is not necessarily the authority and hope of his people. In the language of religion, to execute their power, many rulers, kings or sultans were "treacherous" just for fulfill their political interests.

Not far from the signals above, we can seemingly see how the political ethos of the power of the seminary was represented in the Islamic governance system during the reign of the Aceh Darussalam Sultanate around 17-18 AD. The very heartbreaking and scraping event were the birth of the government policy of Sultan Iskandar Sani and Sultanah Safiyatuddin who ordered all his subordinates to act upon the doctrine of Wahdat Al-Wujud and his followers in quite cruel ways. The policy that eventually reaped the controversy was the order to burn the books of Hamzah Fansuri and to put his adherents to death. Nuruddin Ar-Raniri as the great mufti in the palace was ordered to write the book and hold a debate with adherents of Wujudiyah.

The death penalty for the adherents of Wujudiyah left the long-lasting impact of Islamic life in the Nusantara. Therefore, it prompted the Muslim scholars of that time to review the fundamental concepts in Islam such as Muslim, infidel, infidelity zindiq, holiness (religious tolerance). Acehnese scholars who have a strong theological principal was Sheikh Abdurrauf as-Singkili. In some case, As-Sinkili is at odds with Nuruddin Ar-Raniri.

According to the earlier researchers (Azra, 1995; Tudjimah, 1960) [4][7] a lot of Sheikh Nurudin Ar-Raniri's works were born and written because of fulfilling the request and order by Sultan Iskandar Sani and Sultanah Safiyatuddin who disagree with Wahat Al-Wujud. The works were written to stem the spread of the idea of Wahdat al-Wujud's Syamsudin and Hamzah Fansuri as-Sumatrani. ${ }^{1}$ The works of art are in the following

\subsection{The book of Sirat Al-Mustaqim}

Sheikh Nuruddin Ar-Raniri was a scholar who greatly upheld of the Shari'ah and practicing tasauf (sufism). Therefore, in the field of jurisprudence, he wrote the book of Sirat alMustaqim. ${ }^{3}$ In this work, Nuruddin emphasized the importance of the main task and the fundamentally a muslim in their life. This book of jurisprudence details the ideas that related to ritual of the mahdhoh, such as take an ablution, pilgrimage, fasting, sacrifice, salat, zakat and more. According to Tudjimah (1960) [7], the Sirat Al-Mustaqim was written from $1044 \mathrm{H}$ and completed in $1054 \mathrm{H}$.

\subsection{The Book of Asrar al-Insan fi Ma'rifatil ar-Ruh wa arRahman}

This book contains all kinds of spirits, intellect, qalbu, sirr, lust and habit, all manner of nature, human nature, and more. For against idea of Hamzah Fansuri and Wujudiyah, that says the soul is qadim. According to Ar-Raniri, the soul is a hadith (new), because it is created by God. So Nuruddin strongly opposed term "Ana Al-Haq". In the book of Asrar al Insan, it is also stated that the phrase "man 'arafa nafsahu faqad' arafa rabbahu" means "Whoever knows himself (as a creature), he will be able to know his God (as the Creator). Who knows himself as mortal beings, then he will know God 's All Breed.

\footnotetext{
${ }^{1}$ For more on Nuruddin Ar-Raniri's works, read Chamamah Soeratmo, 1980. "Understanding Nurudin Ar-Raniri's Works" by the research of the FS UGM, Yogjakarta
} 


\subsection{The Book of Tibyan fi Ma'rifatil Adyan}

Tibyan, according to Azra (1995) [4] appears to be designed as the Book of Al-Milal wa wa al-Nihal the famous work on comparison of religion by Al-Syahrastani, but on most of its books, Tibyan closer to Al-Tamhid by Abu Shahur Al-Salim. According to Voorhoeve in his essay "Van en over Nuruddin ar-Raniri" (BKI, 137: 355), the Book of Tibyan fi Ma'rifatil Adyan (The Explanatory Introduction to Religions) was written around $1056 \mathrm{H}$. In Malay at the beginning of the book, it was written after the death of Sultan Iskandar Sani during the reign of the Sultanah Taj 'Alam Safiyatuddin Syah, Nuruddin was given orders to write a book on religion and his orders (sufism). Then Nuruddin started writing this book. This book is about comparison of religion.

\section{Conclusion}

The conclusions that can be drawn from the analysis of the origin of literary works are as follows:

a. The hegemony of the sultan's political power seemed very sadistic when he ordered the royal army to burn out Hamzah Fansri's works for allegedly misleading Muslims, and to punish Hamzah Fansuri and his followers. This event traces the dark history of the Islamic political map in the Nusantara.

b. Many of the works of Nuruddin Ar-Raniri were born and written under the orders of Sultan Iskandar Sani and Sultanah Safiyatuddin. The origin of the literary works is that they are influenced by the author's dislike of the idea of the Wujudiyah atau wahdat al-wujud. To suppress the idea of Hamzah Fansuri, Nuruddin was ordered to write the correct book of aqiah and tasauf. The literary works are The Book of Asrar Al-Insan Fi Ma'rifatir Ruh Wa Ar-Rahman, Tibyan Fi Ma'rifatil Adyan, and Durrat al-Faraid bi Syarh al-'Aqaid.

c. The books of Nuruddin ar-Raniri are powerful enough to teach the people of Wujudiyah that is Asrar Al-Insan and Durrat Al-Fara'id. This is because the books teach about the attributes of God, the existence of absolute, absolute, distinct beings, beings, different from nature and man, Laisa kamislihi syai'un. Whereas the Wujudiyah teaches that there is a unity between God and nature, God and man ( pantheistic).

d. The events of the "religious court" carried out by Nurudin and the sultan in the Aceh regime have invoked a crusade among scholars, both domestic and foreign. From within the country was born a sharp criticism of Sheikh Abdura Rauf As-Singkili who harshly condemned the case. The response of foreign scholars came from the Mecca scholar, Sheikh Ahmad al-Qusyasyi, who argued that the doctrine of the Wujudiyah in Aceh was not heresy because it was based on the doctrine of Haq.

e. The effect of the sultan's political policies on the scholars and the religious affairs that did not bring justice to the Muslim community at that time had brought political and community conditions to heats up. Therefore, slowly but surely, that the Aceh sultanate's government suffered a severe setback, eventually leading to the collapse of the kingdom of Nangro Aceh Darussalam to its downfall.

\section{References}

[1] A. H. John, Malay Sufism. Oxford: The Alden Press, 1975.

[2] Simuh, Mistik Islam Kejawen Raden Ngabehi Ranggawarsita: Suatu Studi Terhadap Serat Wirid Hidayat Jati. Jakarta: UI Press, 1988. 
[3] A. Schimmel, "Dimensi Mistik dalam Islam, terj," Sapardi Djoko Damono, et. al.,(Jakarta Pustaka Firdaus, 2000), 1986.

[4] A. Azra, Jaringan Ulama Timur Tengah dan Kepulauan Nusantara Abad XVII -XVIII. Bandung: Mizan, 1995.

[5] A. Daudy, Syeikh Nuruddin ar-Raniry: sejarah, karya dan sanggahan terhadap Wujudiyyah di Aceh. Bulan Bintang, 1978.

[6] C. A. O. Van Nieuwenhuijze, Samsu 'l-dìn van Pasai: bijdrage tot de kennis der sumatraansche mystiek, vol. 8. EJ Brill, 1945.

[7] Tudjimah, Asrar Al-Insan Fi Ma'rifatir Ruh Wa Ar-Rahman. Jakarta: Djambatan, 1960. 